\title{
Mechanisms by which the infection of Sclerotinia sclerotiorum (Lib.) de Bary affects the photosynthetic performance in tobacco leaves
}

\author{
Cheng Yang ${ }^{1,2 \dagger}$, Zishan Zhang ${ }^{1 \dagger}$, Huiyuan Gao ${ }^{1 *}$, Meijun Liu ${ }^{1}$ and Xingli Fan ${ }^{1}$
}

\begin{abstract}
Background: Sclerotinia sclerotiorum (Lib.) de Bary is a necrotrophic fungal pathogen which causes disease in a wide range of plants. An observed decrease in photosynthetic performance is the primary reason for the reduction of crop yield induced by S. sclerotiorum. The $\mathrm{H}_{2} \mathrm{C}_{2} \mathrm{O}_{4}$ is the main pathogenic material secreted by S. sclerotiorum, but the effects of $\mathrm{H}_{2} \mathrm{C}_{2} \mathrm{O}_{4}$ acidity and the $\mathrm{C}_{2} \mathrm{O}_{4}{ }^{2-}$ ion on photosynthetic performance remain unknown.

Results: $\mathrm{S}$. sclerotiorum infection significantly decreased photosynthetic $\mathrm{O}_{2}$ evolution and the maximum quantum yield of photosystem $\|\left(\mathrm{F}_{\mathrm{v}} / \mathrm{F}_{\mathrm{m}}\right)$ in tobacco leaves under high-light. $\mathrm{H}_{2} \mathrm{C}_{2} \mathrm{O}_{4}$ (the main pathogenic material secreted by S. sclerotiorum) with pH 4.0 also significantly decreased photosynthetic performance. However, treatment with $\mathrm{H}_{3} \mathrm{PO}_{4}$ and $\mathrm{HCl}$ at the same $\mathrm{pH}$ as $\mathrm{H}_{2} \mathrm{C}_{2} \mathrm{O}_{4}$ caused much less decrease in photosynthetic performance than $\mathrm{H}_{2} \mathrm{C}_{2} \mathrm{O}_{4}$ did. These results verify that the acidity of the $\mathrm{H}_{2} \mathrm{C}_{2} \mathrm{O}_{4}$ secreted by $\mathrm{S}$. sclerotiorum was only partially responsible for the observed decreases in photosynthesis. Treatment with $40 \mathrm{mM} \mathrm{K}_{2} \mathrm{C}_{2} \mathrm{O}_{4}$ decreased $\mathrm{F}_{\mathrm{v}} / \mathrm{F}_{\mathrm{m}}$ by about $70 \%$ of the levels observed under $40 \mathrm{mM} \mathrm{H}_{2} \mathrm{C}_{2} \mathrm{O}_{4}$, which further demonstrates that $\mathrm{C}_{2} \mathrm{O}_{4}{ }^{2-}$ was the primary factor that impaired photosynthetic performance during $\mathrm{S}$. sclerotiorum infection. $\mathrm{K}_{2} \mathrm{C}_{2} \mathrm{O}_{4}$ treatment did not further decrease photosynthetic performance when D1 protein synthesis was fully inhibited, indicating that $\mathrm{C}_{2} \mathrm{O}_{4}{ }^{2-}$ inhibited PSII by repressing D1 protein synthesis. It was observed that $\mathrm{K}_{2} \mathrm{C}_{2} \mathrm{O}_{4}$ treatment inhibited the rate of $\mathrm{RuBP}$ regeneration and carboxylation efficiency. In the presence of a carbon assimilation inhibitor, $\mathrm{K}_{2} \mathrm{C}_{2} \mathrm{O}_{4}{ }^{2}$ treatment did not further decrease photosynthetic performance, which infers that $\mathrm{C}_{2} \mathrm{O}_{4}{ }^{2-}$ inhibited PSII activity partly by repressing the carbon assimilation. In addition, it was showed that $\mathrm{C}_{2} \mathrm{O}_{4}{ }^{2-}$ treatment inhibited the PSIl activity but not the PSI activity.

Conclusions: This study demonstrated that the damage to the photosynthetic apparatus induced by $\mathrm{S}$. sclerotiorum is not only caused by the acidity of $\mathrm{H}_{2} \mathrm{C}_{2} \mathrm{O}_{4}$, but also by $\mathrm{C}_{2} \mathrm{O}_{4}{ }^{2-}$ which plays a much more important role in damaging the photosynthetic apparatus. $\mathrm{C}_{2} \mathrm{O}_{4}{ }^{2-}$ inhibits PSIl activity, as well as the rate of RuBP regeneration and carboxylation efficiency, leading to the over production of reactive oxygen species (ROS). By inhibiting the synthesis of D1, ROS may further accelerate PSII photoinhibition.
\end{abstract}

\section{Background}

Sclerotinia sclerotiorum (Lib.) de Bary is a necrotrophic fungal pathogen which causes disease in a wide range of plants, leading to enormous crop reduction [1,2]. Previous studies demonstrated that $\mathrm{H}_{2} \mathrm{C}_{2} \mathrm{O}_{4}$ is an important pathogenic determinant of S. sclerotiorum. S. sclerotiorum mutants deficient in oxalate biosynthesis were shown to be

\footnotetext{
* Correspondence: gaohy@sdau.edu.cn

${ }^{\dagger}$ Equal contributors

'State Key Lab of Crop Biology, College of Life Sciences, Shandong

Agricultural University, Tai'an, Shandong 271018, China

Full list of author information is available at the end of the article
}

less pathogenic than wild-type fungus, and enhancement of $\mathrm{H}_{2} \mathrm{C}_{2} \mathrm{O}_{4}$ degradation capacity was shown to enhance plant resistance to $S$. sclerotiorum [3-5].

A great deal of researches have been conducted on the pathogenic mechanisms of S. sclerotiorum. It was reported that $S$. sclerotiorum can maintain maximal activity of cell wall-degrading enzymes such as polygalacturonase through the acid environment provided by $\mathrm{H}_{2} \mathrm{C}_{2} \mathrm{O}_{4}$ [6]. The cell wall is a natural barrier shield which protects plant tissues from pathogenic bacteria. S. sclerotiorum can weaken the cell wall through chelation of $\mathrm{Ca}^{2+}$ ions present in the cell wall with oxalic ions, breaking down $\mathrm{Ca}^{2+}$-dependent

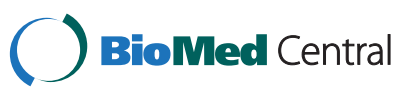

(c) 2014 Yang et al.; licensee BioMed Central Ltd. This is an Open Access article distributed under the terms of the Creative Commons Attribution License (http://creativecommons.org/licenses/by/2.0), which permits unrestricted use, distribution, and reproduction in any medium, provided the original work is properly credited. The Creative Commons Public Domain Dedication waiver (http://creativecommons.org/publicdomain/zero/1.0/) applies to the data made available in this article, unless otherwise stated. 
signal transduction pathways in the host plant [6]. NADPH oxidase, which is involved in reactive oxygen species generation, is required for the pathogenic development and is important for ROS regulation in the successful pathogenesis of S. sclerotiorum [7]. Recently, it was also reported that S. sclerotiorum (via $\mathrm{H}_{2} \mathrm{C}_{2} \mathrm{O}_{4}$ ) generates reducing conditions that suppress host defense responses, including the oxidative burst and callose deposition, during the initial stages of infection. However, once infection is established, S. sclerotiorum benefits to its infection by inducing the generation of plant ROS and programmed cell death (PCD) $[7,8]$.

The leaves of host plant, the primary sites of photosynthesis, are the main targets of many pathogens. The infection of pathogens to the leaves directly reduces photosynthetic performance, leading to drastic losses in crop yield. The repression of photosynthesis in host plants induced by pathogens has been reported in many plant species. For example, photosynthesis was decreased in barley infected by B. graminis [9]. And downregulation of photosystem II quantum yield in host plants occurred during the infection of Pseudomonas syringae [10], Albugo candida [11], Puccinia coronata and Blumeria graminis [9,12], as well as Botrytis cinerea [13]. It was also reported that the expression of sugarregulated photosynthetic genes, such as the small subunit of ribulose-1,5-bisphosphate carboxylase and chlorophyll $a, b$ binding protein, in most cases, were down-regulated after pathogen infection [14].

S. sclerotiorum infection could also decrease photosynthetic performance in host plants. During S. sclerotiorum infection, $\mathrm{H}_{2} \mathrm{C}_{2} \mathrm{O}_{4}$ promotes the accumulation of osmotically active molecules, inducing stomatal opening and inhibiting ABA induced stomatal closure, leading to foliar wilting [15]. In our previous work, S. sclerotiorum infection was shown to induce the over-accumulation of $\mathrm{H}_{2} \mathrm{O}_{2}$ in cucumber leaves due to inhibition of the activity of catalase, damaging the functions of photosystem I (PSI) and photosystem II (PSII) [16]. Although $\mathrm{H}_{2} \mathrm{C}_{2} \mathrm{O}_{4}$ was determined to be the main toxin secreted by $S$. sclerotiorum, it is still unknown whether the destructive effect of S. sclerotiorum on the host photosynthetic apparatus is due to the acidity of $\mathrm{H}_{2} \mathrm{C}_{2} \mathrm{O}_{4}$ or the effect of the $\mathrm{C}_{2} \mathrm{O}_{4}{ }^{2-}$ anion, and if either of them has a deleterious effect, what is the mechanism of impairment of photosynthetic performance?

In order to address this question, we compared the effect of $\mathrm{H}_{2} \mathrm{C}_{2} \mathrm{O}_{4}$ acidity and $\mathrm{C}_{2} \mathrm{O}_{4}{ }^{2-}$ ion on the photosynthetic performance of tobacco leaves, and studied the effects of $\mathrm{C}_{2} \mathrm{O}_{4}{ }^{2-}$ on the photosynthetic electron transport chain, carbon assimilation, the production of ROS and the synthesis of D1 protein in tobacco leaves under high-light treatment. The PSI activity and cyclic electron transport activity were also measured using modulated $820 \mathrm{~nm}$ reflection $\left(\mathrm{MR}_{820 \mathrm{~nm}}\right)$ techniques [17-19].

\section{Results}

Effect of S. sclerotiorum infection on $\mathrm{O}_{2}$ evolution and PSII activity of leaves

The $\mathrm{O}_{2}$ evolution rate reflects the capacity of the photosynthetic apparatus, including both the electron transport chain and carbon assimilation. The fluorescence parameter $\mathrm{F}_{\mathrm{v}} / \mathrm{F}_{\mathrm{m}}$, providing an estimate of the maximum quantum yield of primary photochemistry, is widely used to reflect the extent of photoinhibition $[20,21]$. Both the photosynthetic $\mathrm{O}_{2}$ evolution rate and $\mathrm{F}_{\mathrm{v}} / \mathrm{F}_{\mathrm{m}}$ decreased significantly in leaves infected with $S$. sclerotiorum when compared with controls, and the decreasing extent increased with the lasting of infection (Figure 1). This result indicates that $S$. sclerotiorum infection significantly inhibited photosynthesis and aggravated the photoinhibition in tobacco leaves under high-light.

\section{The effect of $\mathrm{H}_{2} \mathrm{C}_{2} \mathrm{O}_{4}$ and other acids on the activity of PSII}

It has been proved that $\mathrm{H}_{2} \mathrm{C}_{2} \mathrm{O}_{4}$ is the primary pathogenic material secreted by $S$. sclerotiorum [22-24]. Additionally, injection of exogenous $\mathrm{H}_{2} \mathrm{C}_{2} \mathrm{O}_{4}$ can mimic disease symptoms of an actual fungal infection [6,25]. So $\mathrm{H}_{2} \mathrm{C}_{2} \mathrm{O}_{4}$ was used in the following experiments to study the effect of S. sclerotiorum on the photosynthetic performance in host plants. Because the $\mathrm{pH}$ and concentration of $\mathrm{H}_{2} \mathrm{C}_{2} \mathrm{O}_{4}$ in the culture solution of S. sclerotiorum were 4.0 and $40 \mathrm{mM}$ respectively after 14 days growing of the S. sclerotiorum, $40 \mathrm{mM} \mathrm{H}_{2} \mathrm{C}_{2} \mathrm{O}_{4}$ with $\mathrm{pH} 4.0$ (adjusted with $\mathrm{KOH}$ ) was used to treat leaves in this experiment.

In order to distinguish the effect of $\mathrm{H}_{2} \mathrm{C}_{2} \mathrm{O}_{4}$-mediated acidity from the effect of $\mathrm{C}_{2} \mathrm{O}_{4}{ }^{2-}$ anion on photosynthetic performance, the effects of acidity ( $\mathrm{pH} 4.0$ ) provided by $\mathrm{H}_{2} \mathrm{C}_{2} \mathrm{O}_{4}$ (40 mM, pH adjusted to 4.0 with $\mathrm{KOH}), \mathrm{H}_{3} \mathrm{PO}_{4}$ and $\mathrm{HCl}$, respectively, were compared to $40 \mathrm{mM} \mathrm{K}_{2} \mathrm{C}_{2} \mathrm{O}_{4}$.

The $\mathrm{F}_{\mathrm{v}} / \mathrm{F}_{\mathrm{m}}$ decreased significantly in leaves treated with $\mathrm{HCl}(\mathrm{pH} 4.0), \mathrm{H}_{3} \mathrm{PO}_{4}(\mathrm{pH} 4.0), \mathrm{H}_{2} \mathrm{C}_{2} \mathrm{O}_{4}(40 \mathrm{mM}$, $\mathrm{pH}$ adjusted to 4.0$)$ and $\mathrm{K}_{2} \mathrm{C}_{2} \mathrm{O}_{4}(40 \mathrm{mM})$ after highlight treatment (Figure 2A). The decrease of $F_{v} / F_{m}$ in $\mathrm{HCl}$ and $\mathrm{H}_{3} \mathrm{PO}_{4}$ treated leaves was only slightly lower than that in $\mathrm{CK}$ leaves after high-light treatment. However, $\mathrm{H}_{2} \mathrm{C}_{2} \mathrm{O}_{4}$ treatment significantly decreased $\mathrm{F}_{\mathrm{v}} / \mathrm{F}_{\mathrm{m}}$ in tobacco leaves (Figure 2). When $\mathrm{K}_{2} \mathrm{C}_{2} \mathrm{O}_{4}$ was used to eliminate $\mathrm{H}_{2} \mathrm{C}_{2} \mathrm{O}_{4}$ acidity in the experiment, the PSII activity was also severely inhibited under high-light. The extent of $\mathrm{K}_{2} \mathrm{C}_{2} \mathrm{O}_{4}$ inhibition of $\mathrm{F}_{\mathrm{v}} / \mathrm{F}_{\mathrm{m}}$ reached $69.7 \%$ of the inhibition induced by $\mathrm{H}_{2} \mathrm{C}_{2} \mathrm{O}_{4}$ (Figure 2A). Meanwhile, the $\mathrm{F}_{\mathrm{m}}$ of the normalized fluorescence transient in $\mathrm{K}_{2} \mathrm{C}_{2} \mathrm{O}_{4}$ treated leaves decreased much more than that in $\mathrm{HCl}$ and $\mathrm{H}_{3} \mathrm{PO}_{4}$ treated leaves (Figure 2B), and the decreased extent was only a bit smaller than that in $\mathrm{H}_{2} \mathrm{C}_{2} \mathrm{O}_{4}$ treated leaves. The results indicate that the 


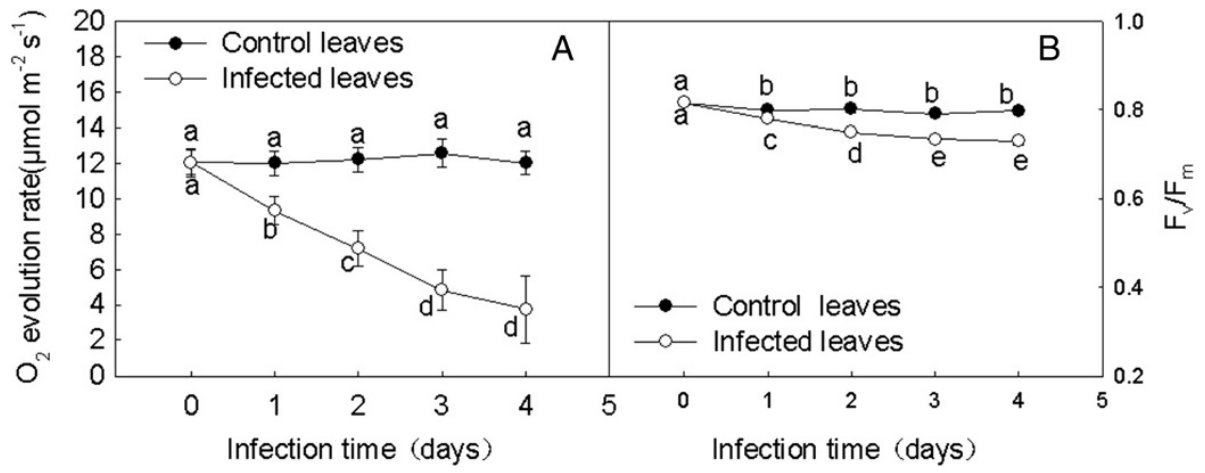

Figure 1 Changes in the photosynthetic $\mathrm{O}_{2}$ evolution rate $(A)$ and the maximum quantum yield of primary photochemistry $\left(F_{v} / F_{m}, B\right)$ in tobacco leaves infected with S. sclerotiorum. $\bullet$, 0 indicate control and infected leaves, respectively. Control leaves were leaves without infection by S. sclerotiorum. Leaf discs used for $\mathrm{O}_{2}$ evolution rate determination and $\mathrm{F}_{\mathrm{v}} / \mathrm{F}_{\mathrm{m}}$ measurement were cut within the region $2 \mathrm{~cm}$ away from the centre of the necrotic spot with a 10-mm cork borer. Different letters indicate significant differences between the leaves with different treatments $(P<0.05)$. Values were means \pm SE $(n=8)$.

influence of $\mathrm{H}_{2} \mathrm{C}_{2} \mathrm{O}_{4}$ on photosynthetic performance was mainly caused by the $\mathrm{C}_{2} \mathrm{O}_{4}{ }^{2-}$ anion.

\section{The effect of different concentrations of $\mathrm{K}_{2} \mathrm{C}_{2} \mathrm{O}_{4}$ on the activity of PSII}

In leaves treated with 20, 40, $60 \mathrm{mM} \mathrm{K}_{2} \mathrm{C}_{2} \mathrm{O}_{4}$ and $120 \mathrm{mM} \mathrm{KCl}, \mathrm{F}_{\mathrm{v}} / \mathrm{F}_{\mathrm{m}}$ decreased significantly in high light (800 $\mu \mathrm{mol} \cdot \mathrm{cm}^{-2} \cdot \mathrm{s}^{-1}$; Figure $\left.3 \mathrm{~A}\right)$. When the treated leaves were placed in low light $\left(50 \mu \mathrm{mol} \cdot \mathrm{cm}^{-2} \cdot \mathrm{s}^{-1}\right)$ for recovery after photoinhibition treatment, the $F_{v} / F_{m}$ in all leaves recovered to a large extent. However, the $F_{v} / F_{m}$ in $\mathrm{K}_{2} \mathrm{C}_{2} \mathrm{O}_{4}$ treated leaves recovered less than that in the control and $\mathrm{KCl}$ treated leaves (Figure 3A). Nonetheless, no significant differences were observed in $F_{v} / F_{m}$ between different treatment groups in the dark (Figure 3B). There was no significant difference in $F_{v} / F_{m}$ between $\mathrm{KCl}$ treated leaves and the control leaves either. Because $120 \mathrm{mM} \mathrm{KCl}$ has the same concentration of $\mathrm{K}^{+}$as
$60 \mathrm{mM} \mathrm{K} \mathrm{C}_{2} \mathrm{O}_{4}$ does, and it has lower osmotic potential than $60 \mathrm{mM} \mathrm{K}_{2} \mathrm{C}_{2} \mathrm{O}_{4}$, the effect of $\mathrm{K}^{+}$and osmotic stress on the result was then neglected.

In high light $\left(800 \mu \mathrm{mol} \cdot \mathrm{cm}^{-2} \cdot \mathrm{s}^{-1}\right)$ for 2 hours, the electron transport rate (ETR) and photochemical quenching ( $\mathrm{qP}$ ) in $\mathrm{K}_{2} \mathrm{C}_{2} \mathrm{O}_{4}$ treated leaves decreased much more than that in control and $\mathrm{KCl}$ treated leaves, meanwhile, NPQ was higher in $\mathrm{K}_{2} \mathrm{C}_{2} \mathrm{O}_{4}$ treated leaves than that in the leaves with other treatment (Figure 4). This result further indicates that $\mathrm{K}_{2} \mathrm{C}_{2} \mathrm{O}_{4}$ treatment aggravates PSII photoinhibition in tobacco leaves under high-light.

In the presence of chloramphenicol $(\mathrm{CM})$, an inhibitor of de novo D1 protein synthesis [26,27], $\mathrm{K}_{2} \mathrm{C}_{2} \mathrm{O}_{4}$ treatment did not aggravate the decrease of $\mathrm{F}_{\mathrm{v}} / \mathrm{F}_{\mathrm{m}}$ (Figure 5). And the large difference in $\mathrm{P}$ point of the OJIP curves between different treatments was eliminated by $\mathrm{CM}$ treatment, which indicates that the inhibition of D1

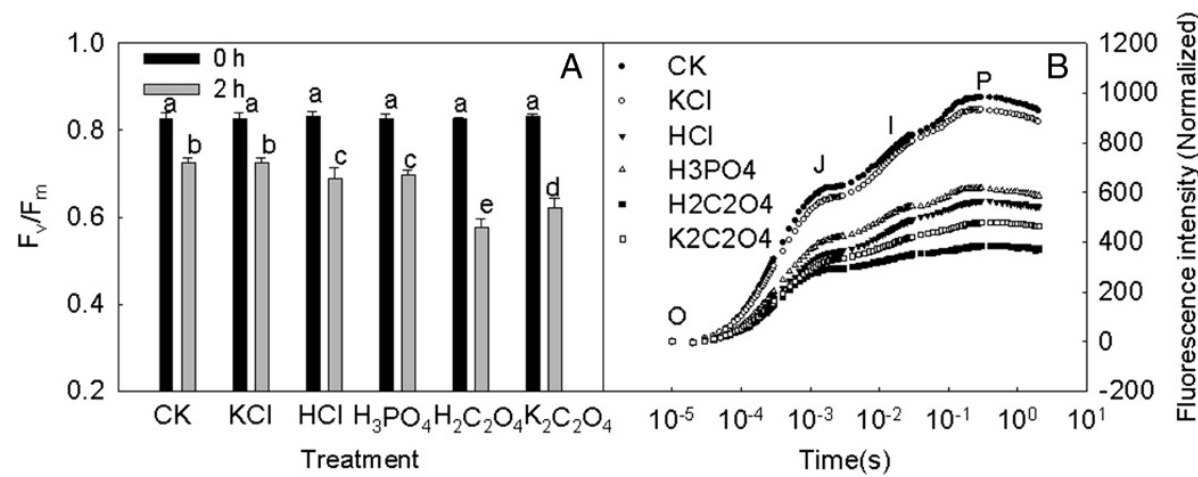

Figure 2 Effect of $\mathrm{HCl}(\mathrm{pH} 4.0), \mathrm{H}_{3} \mathrm{PO}_{4}(\mathrm{pH} 4.0), \mathrm{H}_{2} \mathrm{C}_{2} \mathrm{O}_{4}\left(40 \mathrm{mM}\right.$, pH adjusted to 4.0), $\mathrm{K}_{2} \mathrm{C}_{2} \mathrm{O}_{4}(40 \mathrm{mM})$ and $\mathrm{KCl}(80 \mathrm{mM})$ treatment on $\mathbf{F}_{\mathbf{v}} / \mathbf{F}_{\mathbf{m}}(\mathbf{A})$ and OJIP curves (normalized, B) in tobacco leaves. $\mathbf{a}$ indicates leaves before treatment; $\square$ indicates leaves 2 hours after high-light treatment. Leaf discs (10 mm diameter) were infiltrated with $\mathrm{HCL}(\mathrm{pH} 4.0), \mathrm{H}_{3} \mathrm{PO}_{4}\left(\mathrm{pH}\right.$ 4.0), $\mathrm{H}_{2} \mathrm{C}_{2} \mathrm{O}_{4}(40 \mathrm{mM}$, pH adjusted to 4.0$), \mathrm{K}_{2} \mathrm{C}_{2} \mathrm{O}_{4}$ (40 mM) and $\mathrm{KCl}(80 \mathrm{mM})$ under darkness for $3 \mathrm{~h}$, followed by exposure to high-light $\left(800 \mu \mathrm{mol} \mathrm{m} \mathrm{m}^{-2} \mathrm{~s}^{-1}\right)$ for 2 hours. CK were leaves without any reagent treatment. Different letters indicate significant differences between leaves with different treatments $(P<0.05)$. Values were means $\pm S E(n=8)$. 


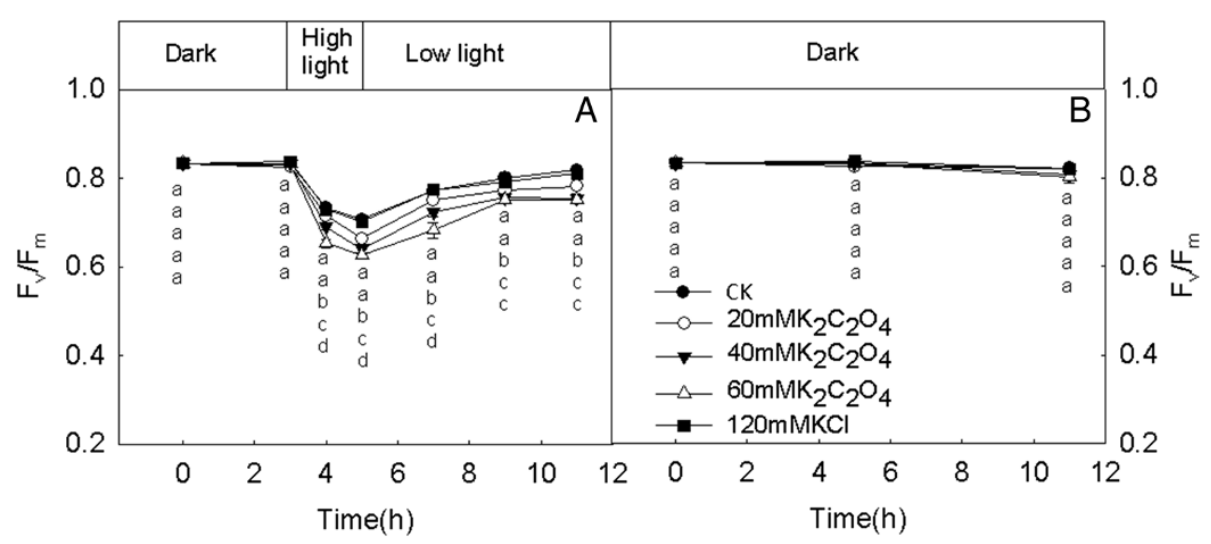

Figure 3 Effect of different concentrations of $\mathrm{K}_{2} \mathrm{C}_{2} \mathrm{O}_{4}$ and $\mathrm{KCl}$ on $\mathrm{F}_{\mathrm{v}} / \mathrm{F}_{\mathrm{m}}(\mathrm{A})$ and OJIP curves (normalized, B) in tobacco leaves. In $\mathrm{A}$, leaves were kept in the dark from 0-3 h, $800 \mu \mathrm{mol} \mathrm{m} \mathrm{m}^{-2} \mathrm{~s}^{-1}$ light from 3-5 h, and $50 \mu \mathrm{mol} \cdot \mathrm{m}^{-2} \cdot \mathrm{s}^{-1}$ light from 5-11 $\mathrm{h}$ to recover. In $\mathbf{B}$, the leaves were kept in the dark the duration of the study. CK were leaves without any reagent treatment. Different letters indicate significant differences between leaves with different treatments $(P<0.05)$. Values were means $\pm S E(n=8)$.

protein by $\mathrm{C}_{2} \mathrm{O}_{4}{ }^{2-}$ accelerated the photoinhibition of PSII in leaves treated with $\mathrm{H}_{2} \mathrm{C}_{2} \mathrm{O}_{4}$ under high-light.

\section{The effect of $\mathrm{K}_{2} \mathrm{C}_{2} \mathrm{O}_{4}$ treatment on the accumulation of hydrogen peroxide $\left(\mathrm{H}_{2} \mathrm{O}_{2}\right)$}

As shown in Figure 6, $\mathrm{K}_{2} \mathrm{C}_{2} \mathrm{O}_{4}$ treatment obviously enhanced the accumulation of $\mathrm{H}_{2} \mathrm{O}_{2}$ in tobacco leaves under high light when compared with control and $\mathrm{KCl}$ treated leaves, which indicates that $\mathrm{K}_{2} \mathrm{C}_{2} \mathrm{O}_{4}$ treated leaves suffered from greater photo-oxidative stress.

\section{The effect of $\mathrm{K}_{2} \mathrm{C}_{2} \mathrm{O}_{4}$ on carbon assimilation}

A photosynthetic model suggests that $\mathrm{CO}_{2}$ assimilation in C3 plants is limited by the rate of RuBP regeneration at high levels of $\mathrm{CO}_{2}$, and is limited by the efficiency of Rubisco at lower levels of $\mathrm{CO}_{2}$ [28]. In tobacco leaves treated with $\mathrm{K}_{2} \mathrm{C}_{2} \mathrm{O}_{4}$, carboxylation efficiency $(\mathrm{CE})$ and net photosynthetic rate $(\mathrm{Pn})$ at saturated $\mathrm{CO}_{2}(\mathrm{Am})$ both decreased severely compared to the control, at magnitudes which increased with $\mathrm{K}_{2} \mathrm{C}_{2} \mathrm{O}_{4}$ concentration (Figure 7). However, no significant decreases in $\mathrm{CE}$ and $\mathrm{Am}$ were observed in leaves treated with $120 \mathrm{mM} \mathrm{KCl}$. It suggests that $\mathrm{C}_{2} \mathrm{O}_{4}{ }^{2-}$ inhibited both Rubisco activity and RuBP regeneration. In addition, after exposed to light for $2 \mathrm{~h}$, the contents of both soluble sugar and starch in $\mathrm{K}_{2} \mathrm{C}_{2} \mathrm{O}_{4}$ treated leaves were significantly lower than those in control and $\mathrm{KCl}$ treated leaves (Figure 8), which demonstrates that $\mathrm{C}_{2} \mathrm{O}_{4}{ }^{2-}$ significantly inhibited Calvin cycle.

To further investigate the effect of $\mathrm{K}_{2} \mathrm{C}_{2} \mathrm{O}_{4}$ on carbon assimilation, leaves were pretreated with iodoacetamide (IAM), an inhibitor of the Calvin cycle $[29,30]$. In the presence of IAM, no significant differences were observed in $\mathrm{F}_{\mathrm{v}} / \mathrm{F}_{\mathrm{m}}$ between $\mathrm{K}_{2} \mathrm{C}_{2} \mathrm{O}_{4}$ treated leaves and control leaves after high light treatment (Figure 9). This result implies that when $\mathrm{CO}_{2}$ assimilation was inhibited, $\mathrm{K}_{2} \mathrm{C}_{2} \mathrm{O}_{4}$ didn't further aggravate the photoinhibition under high light proving that the severe photoinhibition caused by the $\mathrm{K}_{2} \mathrm{C}_{2} \mathrm{O}_{4}$ may be due in part to inhibition of the Calvin cycle. The inference was also supported by the fact that IAM treatment eliminated the difference in OJIP curves between $\mathrm{K}_{2} \mathrm{C}_{2} \mathrm{O}_{4}$ treated leaves and CK.

\section{The effect of $\mathrm{K}_{2} \mathrm{C}_{2} \mathrm{O}_{4}$ on PSI activity and cyclic electron flow}

The PSI activities in control leaves, and leaves treated with $\mathrm{KCl}$ and $\mathrm{K}_{2} \mathrm{C}_{2} \mathrm{O}_{4}$ were measured. No significant differences were observed in PSI activity between leaves with different treatments (Figure 10). However, the initial increase rate of $\mathrm{MR}_{820 \mathrm{~nm}}$ in $\mathrm{K}_{2} \mathrm{C}_{2} \mathrm{O}_{4}$ treated leaves after far-red illumination significantly decreased (Figure 11), which indicates a decrease in cyclic electron flow in $\mathrm{K}_{2} \mathrm{C}_{2} \mathrm{O}_{4}$ treated leaves.

\section{Discussion}

S. sclerotiorum infection significantly inhibited photosynthesis (Figure 1), which suggests that the photosynthetic apparatus is a major pathogenic target. In this study, we demonstrated that $\mathrm{H}_{2} \mathrm{C}_{2} \mathrm{O}_{4}$, the most important pathogenic determinant of $\mathrm{S}$. sclerotiorum infection, inhibited photosynthetic activity in tobacco leaves more severely than $\mathrm{HCl}$ and $\mathrm{H}_{3} \mathrm{PO}_{4}$ did at the same $\mathrm{pH}$. The $\mathrm{C}_{2} \mathrm{O}_{4}{ }^{2-}$ anion appeared to play a more important role in damaging the photosynthetic performance than the acidity did, which was supported by the fact that the inhibition of $\mathrm{K}_{2} \mathrm{C}_{2} \mathrm{O}_{4}$ on PSII activity reached about $70 \%$ of the effect observed with $\mathrm{H}_{2} \mathrm{C}_{2} \mathrm{O}_{4}$ (Figure 2).

Therefore, $\mathrm{K}_{2} \mathrm{C}_{2} \mathrm{O}_{4}$ was used to study the mechanisms by which $S$. sclerotiorum affects photosynthetic performance in tobacco leaves. It has been known that the infection of S. sclerotiorum decreases chlorophyll content and causes the appearance of chlorotic symptom in host plants. However, the decrease in chlorophyll content 


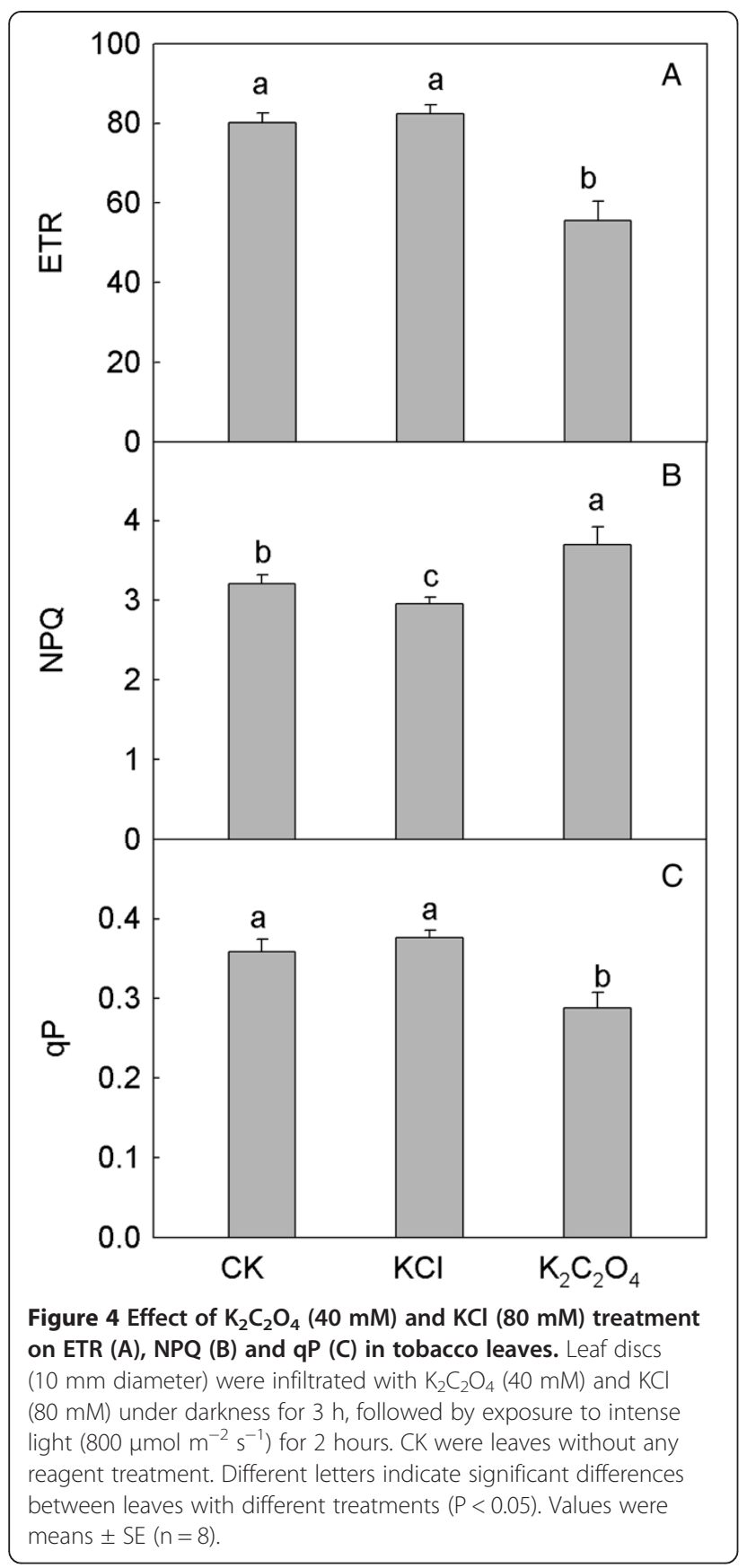

often occurs after infection for several days [31,32], in our experiment, the treatment period is only about $5 \mathrm{~h}$, so the decrease in chlorophyll content didn't occur in the experiment (Additional file 1: Figure S1). The result indicates that the effect of $\mathrm{K}_{2} \mathrm{C}_{2} \mathrm{O}_{4}$ on photosynthetic apparatus does not depend on the degradation of chlorophyll.

$\mathrm{Fv} / \mathrm{Fm}$, ETR and qP decreased significantly in $\mathrm{K}_{2} \mathrm{C}_{2} \mathrm{O}_{4}$ treated leaves but the NPQ increased, indicating that the activity of PSII was significantly damaged by $\mathrm{C}_{2} \mathrm{O}_{4}{ }^{2-}$.We propose that during $S$. sclerotiorum infection, the decreased
PSII activity was probably due to the damage to the reaction centre and acceptor side of PSII by $\mathrm{C}_{2} \mathrm{O}_{4}{ }^{2-}$ secreted by $S$. sclerotiorum because there was no difference observed in $\mathrm{W}_{\mathrm{k}}$ (an indicator of the activity of the donor side of PSII $[33,34]$ ) between $\mathrm{K}_{2} \mathrm{C}_{2} \mathrm{O}_{4}$ treated leaves and control leaves (Additional file 2: Figure S2), and $\Psi_{\mathrm{o}}$ (an indicator of electron transport at PSII acceptor side [35]) decreased in $\mathrm{K}_{2} \mathrm{C}_{2} \mathrm{O}_{4}$ treated leaves (Additional file 3: Figure S3). In the dark, no significant difference was observed in $F_{v} / F_{m}$ between $\mathrm{K}_{2} \mathrm{C}_{2} \mathrm{O}_{4}$ treated leaves and control (Figure 4), demonstrating that $\mathrm{C}_{2} \mathrm{O}_{4}{ }^{2-}$ inhibited the photosynthetic electron transfer chain in an indirect, light-dependent manner.

PSII photoinhibition occurs when the absorbed light is more than it can be used by photochemistry $[36,37]$. However, photosynthetic organisms are able to overcome PSII photoinhibition by rapidly and efficiently repairing the damage, which requires the synthesis of proteins de novo, such as D1 [26]. Under high-light, the PSII activity depends on the balance between the rates of photodamage and repair; consequently, photoinhibition of PSII becomes apparent when the rate of photodamage exceeds the rate of repair [38-40]. As observed in the study, in the presence of $\mathrm{CM}$, the $\mathrm{K}_{2} \mathrm{C}_{2} \mathrm{O}_{4}$ mediated decrease of $\mathrm{F}_{\mathrm{v}} / \mathrm{F}_{\mathrm{m}}$ and changes of OJIP curves were eliminated (Figure 5), which indicates that inactivation of PSII by the $\mathrm{C}_{2} \mathrm{O}_{4}{ }^{2-}$ was largely caused by inhibition of D1 protein synthesis. Recently, it was suggested that all environmental stresses enhance photoinhibition through an indirect method - promoting the production of ROS to inhibit the repair of the D1 protein [40,41]. In this study, a marked increase of $\mathrm{H}_{2} \mathrm{O}_{2}$ was observed in leaves treated with $\mathrm{C}_{2} \mathrm{O}_{4}{ }^{2-}$ (Figure 6), inferring that the increase of the ROS may inhibit D1 protein synthesis. However, further study is needed to clarify whether D1 protein synthesis was inhibited by accumulation of ROS caused by $\mathrm{C}_{2} \mathrm{O}_{4}{ }^{2-}$, or via some combination of the accumulation of ROS and $\mathrm{C}_{2} \mathrm{O}_{4}^{2-}$ direct effect.

The chloroplast photosynthetic electron transport chain is one of the major sites of ROS production in leaves of green plants [42-44]. The photosynthetic electron transport and carbon assimilation work coordinately under normal physiological conditions. The damage or inhibition of either one of the two components would lead to increased ROS production. The fact that both the $\mathrm{CE}$ and Am were significantly inhibited by $\mathrm{C}_{2} \mathrm{O}_{4}{ }^{2-}$ indicates that carbon assimilation processes, including both Rubisco activity and RuBP regeneration (Figure 7 and Additional file 4: Figure $\mathrm{S} 4$ ), were inhibited by $\mathrm{C}_{2} \mathrm{O}_{4}{ }^{2-}$ under highlight, which is further supported by the decrease in the content of soluble sugar and starch in $\mathrm{K}_{2} \mathrm{C}_{2} \mathrm{O}_{4}$ treated leaves (Figure 8). We suggest that the over accumulation of ROS resulted from the inhibition of $\mathrm{CO}_{2}$ assimilation enhanced $\mathrm{C}_{2} \mathrm{O}_{4}{ }^{2-}$ mediated photoinhibition. This was 


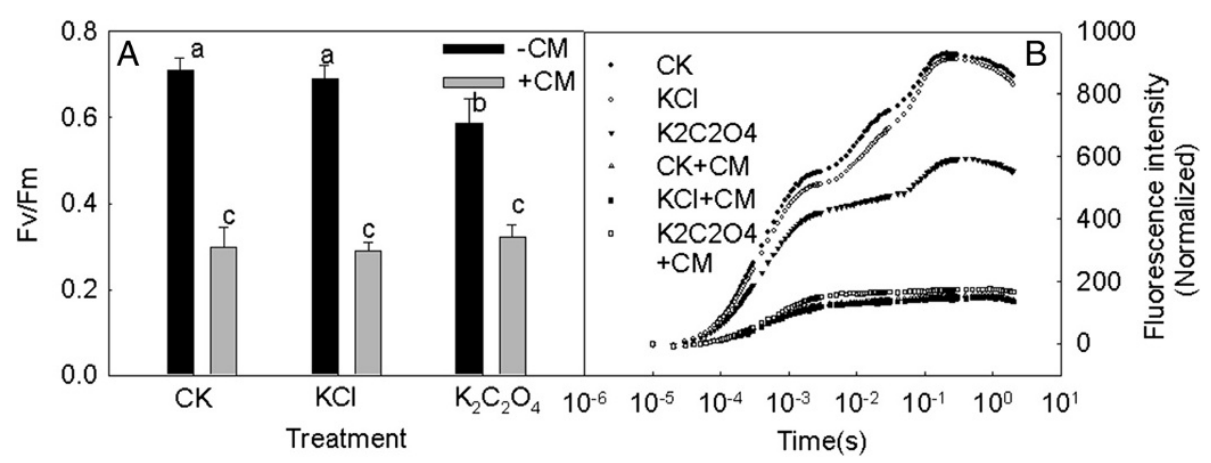

Figure 5 The effect of $40 \mathrm{mM} \mathrm{K} \mathrm{C}_{2} \mathrm{O}_{4}$ and $80 \mathrm{mM} \mathrm{KCl}$ treatment on the $\mathrm{F}_{\mathrm{v}} / \mathrm{F}_{\mathrm{m}} \quad$ (A) and OJIP curves (normalized, B) in tobacco leaves in the presence of chloramphenicol (CM). $\mathbf{m},-\mathrm{CM} ; \mathrm{\square},+\mathrm{CM}$. Leaf discs (10 mm diameter) were immersed into solutions with $1 \mathrm{mM} C \mathrm{CM}$ for $3 \mathrm{~h}$ in the dark, then kept in high light $\left(800 \mu \mathrm{mol} \mathrm{m} \mathrm{m}^{-2} \mathrm{~s}^{-1}\right)$ for $2 \mathrm{~h}$. $\mathrm{F}_{\mathrm{v}} / \mathrm{F}_{\mathrm{m}}$ and $\psi_{\mathrm{o}}$ were measured after $2 \mathrm{~h}$ high light treatment. CK were leaves without $\mathrm{K}_{2} \mathrm{C}_{2} \mathrm{O}_{4}$ and $\mathrm{KCl}$ treatment. Different letters indicate significant differences between leaves with different treatments $(P<0.05)$. Values were means $\pm S E(n=8)$.

further supported by the fact that IAM treatment eliminated the decrease in Fv/Fm (Figure 9) and the changes of OJIP curves induced by $\mathrm{K}_{2} \mathrm{C}_{2} \mathrm{O}_{4}$ under high-light.

It is known that $\mathrm{C}_{2} \mathrm{O}_{4}{ }^{2-}$ can react with many metal ions to form chelate compounds. Rubisco and fructose1, 6-bisphosphatase are key enzymes in Calvin cycle. It has been reported that $\mathrm{Ca}^{2+}$ and $\mathrm{Mg}^{2+}$ play important roles in the regulation of the activity of chloroplast fructose-1,6-bisphosphatase [45,46], and $\mathrm{Mg}^{2+}$ has a enhancing effect on the Rubisco activity [47]. We presume the increased $\mathrm{C}_{2} \mathrm{O}_{4}{ }^{2-}$ in plant cells may decrease the activity of Rubisco or fructose-1,6-bisphosphatase through forming chelate compounds with $\mathrm{Ca}^{2+}$ or $\mathrm{Mg}^{2+}$ in chloroplast. Moreover, the signal role of $\mathrm{H}_{2} \mathrm{C}_{2} \mathrm{O}_{4}$ during

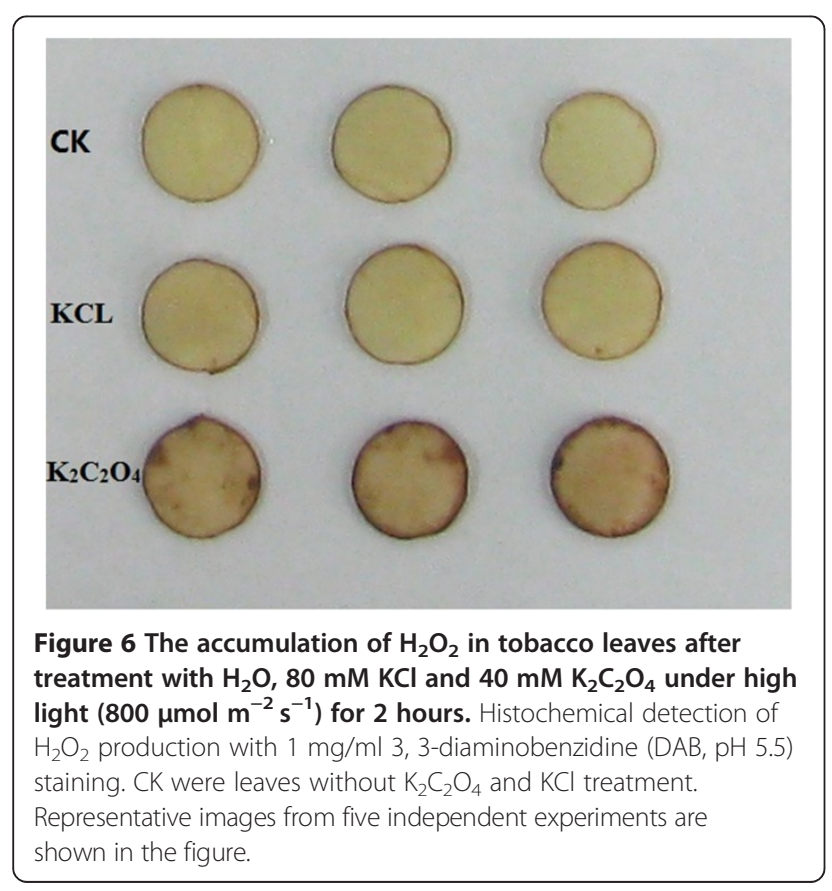

the infection of $S$. sclerotiorum has been demonstrated $[7,8,48]$, the increased $\mathrm{C}_{2} \mathrm{O}_{4}{ }^{2-}$ in plant cells may also interfere with $\mathrm{CO}_{2}$ assimilation through signal transduction. However, to determine the specific mechanism by which $\mathrm{C}_{2} \mathrm{O}_{4}{ }^{2-}$ inhibit the Calvin cycle needs further studies.

Under high-light treatment, though PSI activity was not damaged by $\mathrm{C}_{2} \mathrm{O}_{4}{ }^{2-}$ (Figure 10), cyclic electron flow around PSI was decreased by $\mathrm{K}_{2} \mathrm{C}_{2} \mathrm{O}_{4}$ treatment (Figure 11). The over-reducing of PSI acceptors, always leading to the increase of the generation of superoxide, would be prevented by an increase of cyclic electron flow around PSI [49]. Moreover, the cyclic electron flow can also decrease the probability that singlet oxygen generates within PSII through charge recombination [50,51]. Further studies are needed to clarify whether the decrease in cyclic electron flow induced by $\mathrm{C}_{2} \mathrm{O}_{4}{ }^{2-}$ is correlated to the increase in ROS generation and the enhancement of PSII photoinhibition in $\mathrm{K}_{2} \mathrm{C}_{2} \mathrm{O}_{4}$ treated leaves.

Our experiment demonstrated that it is the $\mathrm{C}_{2} \mathrm{O}_{4}{ }^{2-}$ ion secreted by $\mathrm{S}$. sclerotiorum rather than the decrease in $\mathrm{pH}$ caused by the $\mathrm{H}_{2} \mathrm{C}_{2} \mathrm{O}_{4}$ that mainly induces the damage to photosynthetic apparatus. However, we did not exclude that necrosis may also cause inhibition of Calvin cycle and PSII activity. Since the $\mathrm{C}_{2} \mathrm{O}_{4}{ }^{2-}$ ion plays a more important role in impairing photosynthetic apparatus than acidity does, it reasonable to infer that the inhibition of Calvin cycle and PSII activity by necrosis in S. sclerotiorum infected leaves is mainly induced by the $\mathrm{C}_{2} \mathrm{O}_{4}{ }^{2-}$ ion secreted by S. sclerotiorum. $\mathrm{F}_{\mathrm{o}}$ is the fluorescence emitted by antenna pigment of PSII with open reaction center. Chlorophyll content and $\mathrm{F}_{\mathrm{o}}$ all showed no significant difference among the leaves treated with $\mathrm{K}_{2} \mathrm{C}_{2} \mathrm{O}_{4}$, CK and $\mathrm{KCl}$, which indicates that the antenna of PSII might not affected by $\mathrm{C}_{2} \mathrm{O}_{4}{ }^{2-}$ in our experiment (Additional file 1: Figure S1 and Additional file 5: Figure S5). 


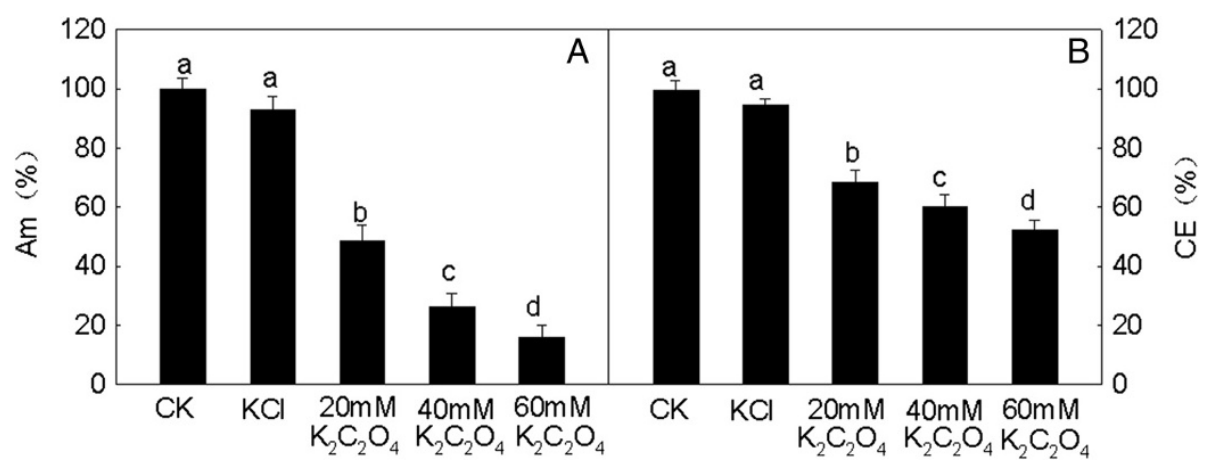

Figure 7 Relative photosynthetic rates at saturated $\mathrm{CO}_{2}(\mathrm{Am}, \mathrm{A})$, and carboxylation efficiency $(\mathrm{CE}, \mathrm{B})$ of tobacco leaves treated with different concentrations $(0,20,40,60 \mathrm{mM})$ of $\mathrm{K}_{2} \mathrm{C}_{2} \mathrm{O}_{4}$ and $120 \mathrm{mM} \mathrm{KCl}$. The petioles of detached leaves were dipped into treatment solutions before measurement in the dark for 3 hours. $\mathrm{CK}$ were leaves without $\mathrm{K}_{2} \mathrm{C}_{2} \mathrm{O}_{4}$ and $\mathrm{KCl}$ treatment. Different letters indicate significant differences between leaves with different treatments $(P<0.05)$. Values shown are means $\pm S E(n=6)$.

\section{Conclusions}

This study demonstrated that $\mathrm{H}_{2} \mathrm{C}_{2} \mathrm{O}_{4}$ secreted by $S$. sclerotiorum enhanced photoinhibition, mainly by the effect of the $\mathrm{C}_{2} \mathrm{O}_{4}^{2-}$ ion. $\mathrm{C}_{2} \mathrm{O}_{4}^{2-}$ led to the decrease of both the activity of Rubisco and RuBP regeneration, leading to the accumulation of $\mathrm{H}_{2} \mathrm{O}_{2}$ in the chloroplast. The over accumulation of $\mathrm{H}_{2} \mathrm{O}_{2}$ inhibited the turnover of the

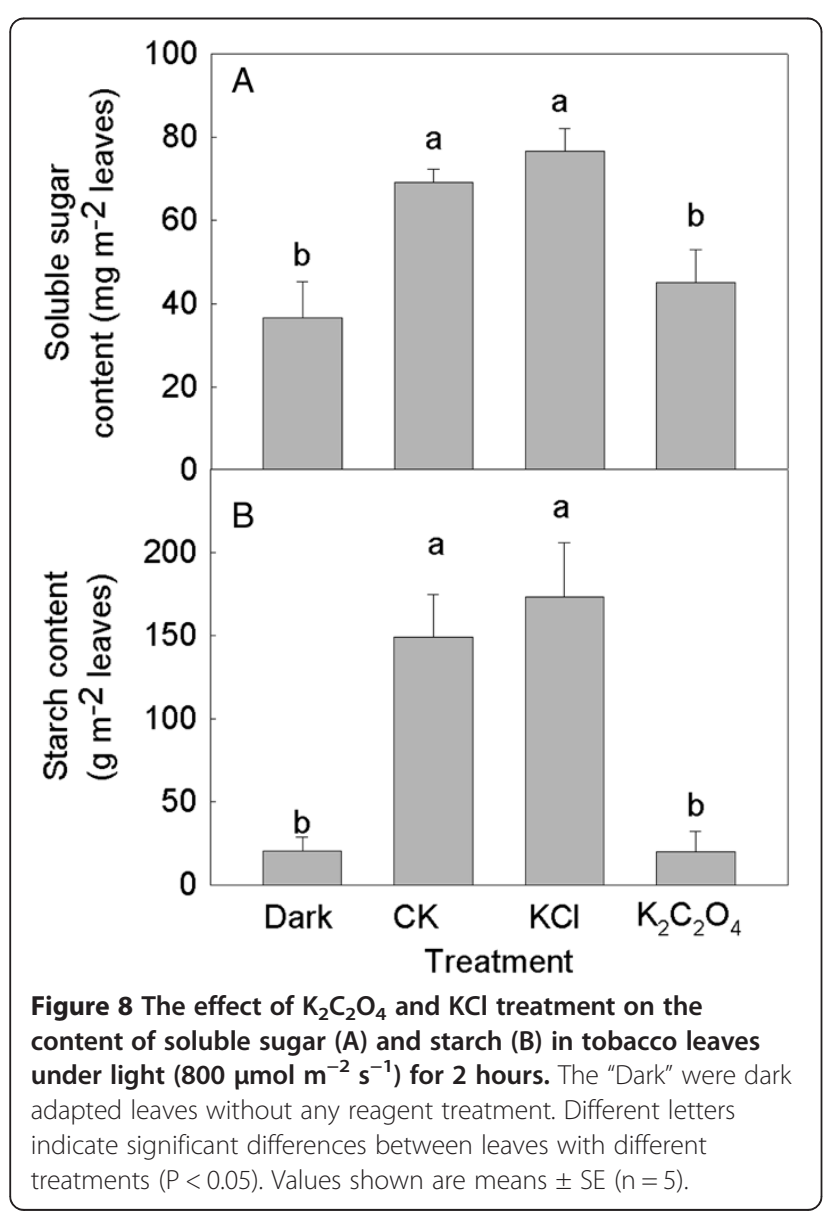

D1 protein. This is likely the primary mechanism by which S. Sclerotiorum infection affects the photosynthetic performance of tobacco leaves. Further studies are needed to explore whether $\mathrm{C}_{2} \mathrm{O}_{4}^{2-}$ has a direct effect on D1 protein synthesis, and to elucidate the detailed mechanisms by which $\mathrm{C}_{2} \mathrm{O}_{4}^{2-}$ inhibits the activity of Rubisco and $\mathrm{RuBP}$ regeneration in tobacco leaves. And if the inhibition of Rubisco activity and RuBP regeneration is mediated by the signal effect of $\mathrm{C}_{2} \mathrm{O}_{4}^{2-}$ and if the decrease in PSII activity caused by $\mathrm{C}_{2} \mathrm{O}_{4}^{2-}$ is involved in the PCD induced by S.Sclerotiorum remain to be elucidated in future work.

\section{Methods}

Plant materials

Tobacco seeds (Nicotiana tabacum L. cv. NC89) were germinated on vermiculite. Thirty days after germination, the seedlings were transplanted to pots containing a compost soil substrate to grow in a greenhouse under a natural photoperiod (day: $25-30^{\circ} \mathrm{C}$, night: $20-25^{\circ} \mathrm{C}$ ). Commercial humus, vermiculite and field soil (1:1:1, v:v:v) were mixed as a compost soil substrate. The pots were periodically irrigated with tap water and fertilized twice a month. Just before flowering, the new fully expanded leaves were used in this experiment.

\section{Fungal growth and plant inoculations}

S. sclerotiorum was grown on PDA culture at $25^{\circ} \mathrm{C}$ in the dark for 3-5 days. After this period, mycelial agar plugs of $10 \mathrm{~mm}$ diameter were excised and transferred to Maxwell \& Lumsden liquid cultures at $25^{\circ} \mathrm{C}$ in the dark for 14 days. The resultant mycelium was taken for use in leaf inoculation, which was performed according to Walz (2008) and $\mathrm{Bu}(2009)$ [16,52]. Leaf segments $2 \mathrm{~cm}$ away from the center of the necrotic spot were cut for measurement of $\mathrm{O}_{2}$ evolution rate and $\mathrm{F}_{\mathrm{v}} / \mathrm{F}_{\mathrm{m}}$. 


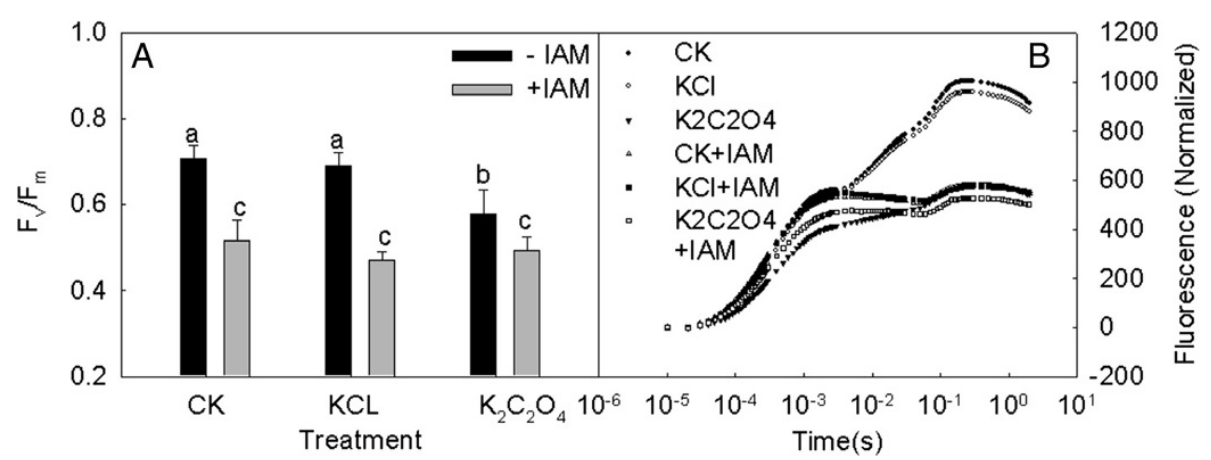

Figure 9 The effect of $40 \mathrm{mM} \mathrm{K} \mathrm{C}_{2} \mathrm{O}_{4}$ and $80 \mathrm{mM} \mathrm{KCl}$ treatment on the $\mathrm{F}_{\mathrm{v}} / \mathrm{F}_{\mathrm{m}}(\mathrm{A}$ ) and OJIP curves (normalized, B) in tobacco leaves under light $\left(800 \mu \mathrm{mol} \mathrm{m} \mathbf{~ m}^{-2} \mathrm{~s}^{-1}\right)$ with or without $1 \mathrm{mM}$ iodoacetamide (IAM). CK were leaves without $\mathrm{K}_{2} \mathrm{C}_{2} \mathrm{O}_{4}$ and $\mathrm{KCl}$ treatment. Different letters indicate significant differences between leaves with different treatments $(P<0.05)$. Values shown are means $\pm S E(n=8)$.

\section{Photosynthetic $\mathrm{O}_{2}$ evolution rate measurement}

A Chlorolab-2 liquid-phase oxygen electrode system (Hansatech Instruments, Norfolk, UK) was used to measure the photosynthetic $\mathrm{O}_{2}$ evolution rates of infected leaf discs in $1 \mathrm{mM} \mathrm{NaHCO}$ solution under saturation light $\left(800 \mu \mathrm{mol} \mathrm{m}^{-2} \mathrm{~s}^{-1}\right)$ at room temperature.

\section{Treatment of plant materials}

Leaf disks (10 mm diameter) obtained from new fully expanded leaves were immersed in $\mathrm{H}_{3} \mathrm{PO}_{4}$ ( $\mathrm{pH}$ 4.0), HCL ( $\mathrm{pH} 4.0$ ), $\mathrm{H}_{2} \mathrm{C}_{2} \mathrm{O}_{4}$ (40 mM, pH adjusted to 4.0 with $\mathrm{KOH}$ ), $40 \mathrm{mM} \mathrm{K} \mathrm{K}_{2} \mathrm{O}_{4}$, or different concentrations (20, 40, $60 \mathrm{mM}$ ) of $\mathrm{K}_{2} \mathrm{C}_{2} \mathrm{O}_{4}$ solution for 3 hours in the dark for sufficient permeation, and then floated on the solution for photoinhibition or recovery treatment. S. sclerotiorum culture medium showed $\mathrm{pH} \sim 4.0$ and $\left[\mathrm{H}_{2} \mathrm{C}_{2} \mathrm{O}_{4}\right] \sim 40 \mathrm{mM}$;

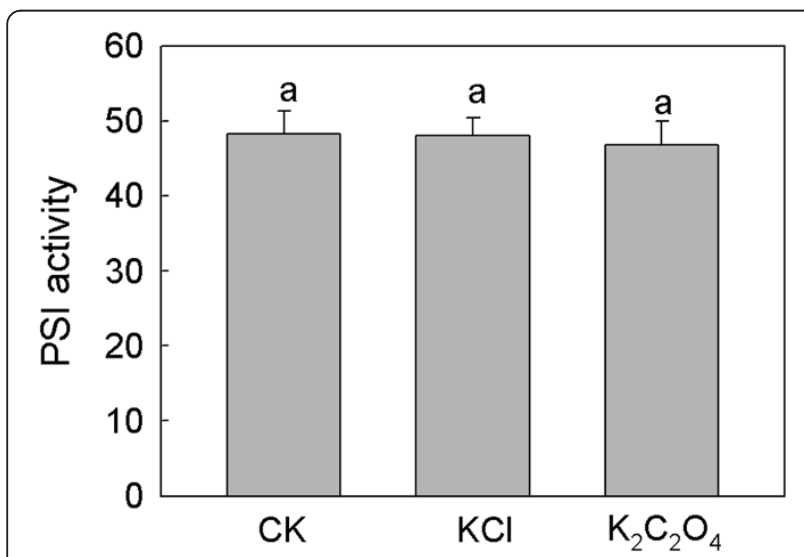

Figure 10 The effect of $\mathrm{K}_{2} \mathrm{C}_{2} \mathrm{O}_{4}$ and $\mathrm{KCl}$ treatment on the PSI activity. The PSI activity of the treated leaves were measured with an M-PEA (Hansatech Instrument Ltd., UK). The induction curve of $\mathrm{MR}_{820 \mathrm{~nm}}$ of the leaves obtained by saturating red light showed a fast oxidation phase and a following reduction phase. The initial slope of the oxidation phase of MR820nm at the beginning of the saturated red light indicates the capability of P700 to get oxidized, which is used to reflect the activity of PSI.
$\mathrm{H}_{3} \mathrm{PO}_{4}, \mathrm{HCL}$ were tested at the same $\mathrm{pH}$. The photoinhibition and recovery of the leaf disks were taken under $800 \mu \mathrm{mol} \cdot \mathrm{m}^{-2} \cdot \mathrm{s}^{-1}$ light and $50 \mu \mathrm{mol} \cdot \mathrm{m}^{-2} \cdot \mathrm{s}^{-1}$ light, respectively.

The first new fully expanded leaves from the top of the tobacco plants were excised from the plants at the end of the petiole. The petioles of the excised leaves were quickly dipped into treatment solutions with a second excision in the solution. Treated leaves were then transferred into a growth chamber at $25^{\circ} \mathrm{C}$ in the dark. Gas exchange parameters were measured after four hours.

\section{Measurement of chlorophyll fluorescence}

Chlorophyll $a$ fluorescence transients were measured at room temperature with a Handy Plant Efficiency Analyzer (Hansatech, UK). Illumination was provided by an array of six high intensity LEDs (with a peak of $650 \mathrm{~nm}$ ) which were focused on the sample surface to provide

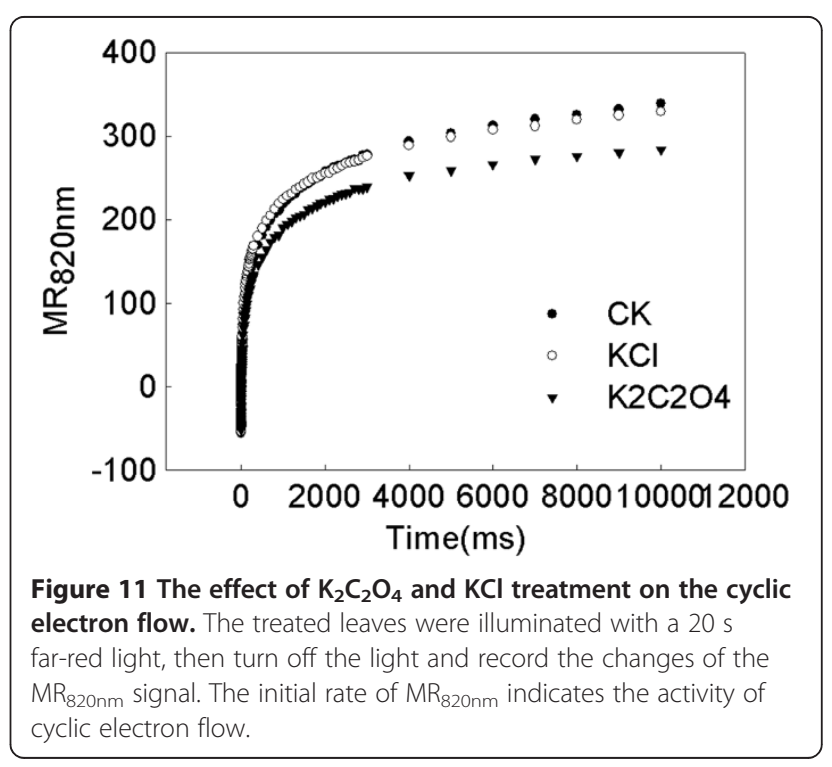


homogeneous illumination over the exposed area of a sample with $4 \mathrm{~mm}$ diameter. Measurements were carried out on leaves dark adapted for 30 min to ensure an initial photochemical activity of zero. During light illumination, chlorophyll $a$ fluorescence intensity in darkadapted leaves rose rapidly from an initial minimal level, $F_{o}$ (the O step), to the maximal level, Fm (P step). Two intermediate steps designated $J$ and I appeared at 2 and $30 \mathrm{~ms}$, respectively; hence, a fast rise of the chlorophyll $a$ fluorescence, transient with the notation $\mathrm{O}-\mathrm{J}-\mathrm{I}-\mathrm{P}$, was obtained.

Chlorophyll $a$ fluorescence transients were analyzed by utilizing the original data from polyphasic fluorescence transients according to the JIP test $[33,53,54]$. The following fluorescence parameters were calculated using the JIP test:

The maximum quantum yield of photosystem II $\left(\mathrm{F}_{\mathrm{v}} / \mathrm{F}_{\mathrm{m}}\right)$, $\mathrm{F}_{\mathrm{v}} / \mathrm{F}_{\mathrm{m}}=\left(\mathrm{F}_{\mathrm{m}}-\mathrm{F}_{\mathrm{o}}\right) / \mathrm{F}_{\mathrm{m}}$; the probability that a trapped exciton moves an electron into the electron transport chain beyond $\mathrm{Q}_{\mathrm{A}}^{-}\left(\Psi_{\mathrm{o}}\right), \Psi_{\mathrm{o}}=1-\mathrm{V}_{\mathrm{j}}=1-\left(\mathrm{F}_{2 \mathrm{~ms}}-\mathrm{F}_{\mathrm{o}}\right) /\left(\mathrm{F}_{\mathrm{m}}-\mathrm{F}_{\mathrm{o}}\right)$; the normalized relative variable fluorescence at the $\mathrm{K}$ band $\left(\mathrm{W}_{\mathrm{k}}\right.$, $\mathrm{K}$ indicates fluorescence extensity at $0.3 \mathrm{~ms}), \mathrm{W}_{\mathrm{k}}=\left(\mathrm{F}_{0.3 \mathrm{~ms}}-\mathrm{F}_{\mathrm{o}}\right) /$ $\left(\mathrm{F}_{2 \mathrm{~ms}}-\mathrm{F}_{\mathrm{o}}\right)$.

\section{Measurements of chlorophyll fluorescence}

Modulated chlorophyll fluorescence was measured with an FMS-2 pulse-modulated fluorometer (Hansatech, UK). The light-fluorescence measurement protocol was as follows: the light-adapted leaves were continuously illuminated by actinic light at $800 \mu \mathrm{mol} \mathrm{m} \mathrm{m}^{-2} \mathrm{~s}^{-1}$ from the FMS-2 light source, steady-state fluorescence $\left(F_{s}\right)$ was recorded after a 2 min illumination, and $0.8 \mathrm{~s}$ of saturating light of $8000 \mu \mathrm{mol} \mathrm{m} \mathrm{m}^{-2} \mathrm{~s}^{-1}$ was imposed to obtain maximum fluorescence in the light-adapted state $\left(\mathrm{F}_{\mathrm{m}}{ }^{\prime}\right)$. The actinic light was then turned off, and the minimum fluorescence in the light-adapted state $\left(\mathrm{F}_{\mathrm{o}}{ }^{\prime}\right)$ was determined by a $3 \mathrm{~s}$ illumination with far-red light.

The following parameters were then calculated [55]:

$$
\begin{aligned}
& \text { Electron transport rate, ETR }=\text { ФPSII } \times \text { PFD } \times 0.5 \times 0.84 \\
& \text { Photochemical quenching, } \mathrm{qP}=\left(\mathrm{F}_{\mathrm{m}}^{\prime}-\mathrm{F}_{\mathrm{s}}\right) /\left(\mathrm{F}_{\mathrm{m}}^{\prime}-\mathrm{F}_{\mathrm{o}}^{\prime}\right) \\
& \text { Non-photochemical quenching, } \mathrm{NPQ}=\left(\mathrm{F}_{\mathrm{m}}-\mathrm{F}_{\mathrm{m}}^{\prime}\right) / \mathrm{F}_{\mathrm{m}}^{\prime}
\end{aligned}
$$

\section{Histochemical detection of $\mathrm{H}_{2} \mathrm{O}_{2}$}

In situ hydrogen peroxide $\left(\mathrm{H}_{2} \mathrm{O}_{2}\right)$ was detected by DAB staining as previously described [56]. $\mathrm{H}_{2} \mathrm{O}_{2}$ reacts with $\mathrm{DAB}$ to form a reddish-brown stain. Treated leaf disks were incubated in $\mathrm{DAB}$ solution, $\mathrm{pH} 5.5$, at $1 \mathrm{mg} / \mathrm{ml}$. After incubation in the dark at room temperature for $20 \mathrm{~h}$, samples were boiled in alcohol (96\%) for $10 \mathrm{~min}$.
After cooling, the leaf discs were extracted at room temperature with fresh ethanol and photographed.

\section{Measurements of gas exchange}

Net photosynthetic rate (Pn), substomatal $\mathrm{CO}_{2}$ concentration $(\mathrm{Ci})$ was measured at room temperature $\left(25^{\circ} \mathrm{C}\right)$ and $60 \%$ relative humidity with a portable system (CIRAS-2, PP Systems, UK). The light intensity was set to $800 \mu \mathrm{mol} \mathrm{m} \mathrm{m}^{-2} \mathrm{~s}^{-1}$. $\mathrm{CO}_{2}$ concentration were changed every $3 \mathrm{~min}$ in a sequence of $2000,1600,1200,800$, $600,400,300,200,150,100$, and $0 \mu \mathrm{mol} \mathrm{mol}^{-1}$. Irradiance and $\mathrm{CO}_{2}$ concentration were controlled by the automatic control function of the CIRAS- 2 photosynthetic system. Carboxylation efficiency was calculated according the initial slop of Pn-Ci response curve.

\section{Measurements of soluble sugar and starch in tobacco leaves}

The samples (25 leave discs) were grounded in doubledistilled water and filtered. The residue was again grounded and filtered. Filtrates were pooled and centrifuged at $10,000 \times \mathrm{g}$ for $15 \mathrm{~min}$. The sample solution $(0.1 \mathrm{~mL})$ was taken in a test tube and made to $1 \mathrm{~mL}$ with double-distilled water. Four millilitre of $0.2 \%$ anthrone reagent $\left(0.2 \mathrm{~g}\right.$ dissolved in $100 \mathrm{~mL}$ conc. $\left.\mathrm{H}_{2} \mathrm{SO}_{4}\right)$ was added, and the contents were heated in a boiling water bath and subsequently cooled. The absorbance was read at $620 \mathrm{~nm}$ [57]. A mixture of $1 \mathrm{~mL}$ distilled water and $4 \mathrm{~mL}$ of $0.2 \%$ anthrone served as blank. The final residue of the leaves after filtered was resuspended in $1.6 \mathrm{M}$ perchloric acid and incubated in a water bath at $70^{\circ} \mathrm{C}$ for $2 \mathrm{~h}$. Then samples were centrifuged at $10000 \mathrm{~g}$ for $10 \mathrm{~min}$ and the carbohydrated concentration in the supernatant was determined via the anthrone method as described above.

\section{Measurements of PSI activity and cylic electron flow around PSI}

The modulated reflection signal measured at $820 \mathrm{~nm}$ $\left(\mathrm{MR}_{820 \mathrm{~nm}}\right)$ provides information about oxidation of PSI (concluding PC and P700). $\mathrm{MR}_{820 \mathrm{~nm}}$ were recorded using a Multifunctional Plant Efficiency Analyzer, MPEA (Hansatech Instrument Ltd., UK).The induction curve of $M_{820 \mathrm{~nm}}$ of the leaves obtained by saturating red light shows a fast oxidation phase and a following reduction phase. The initial slope of oxidation phase of $\mathrm{MR}_{820 \mathrm{~nm}}$ at the beginning of the saturated red light indicates the capability of P700 to get oxidized, which is used to reflect the activity of PSI $[17,18,58]$.

Cylic electron flow around PSI of leaves were measured after leaves were dark adapted for $15 \mathrm{~min}$. After illuminated by far-red light for $20 \mathrm{~s}$, the far-red light was turned off and the $M_{820 n m}$ of the leaves was recorded. The initial increase rate of the $M R_{820 \mathrm{~nm}}$ 
indicates the intensity of cyclic electron flow around PSI [19]. Statistical analysis.

LSD (least significant difference) was used to analyse differences between different treatments by using SPSS 16.

\section{Additional files}

Additional file 1: Figure S1. The effect of $\mathrm{K}_{2} \mathrm{C}_{2} \mathrm{O}_{4}$ and $\mathrm{KCl}$ treatment on the content of pigment in tobacco leaves at the end of treatment. The "Dark" were dark adapted leaves without any reagent treatment. Different letters indicate significant differences between leaves with different treatments $(P<0.05)$. Values shown are means $\pm S E(n=5)$.

Additional file 2: Figure S2. Effect of $\mathrm{HCl}(\mathrm{pH} 4.0), \mathrm{H}_{3} \mathrm{PO}_{4}(\mathrm{pH}$ 4.0), $\mathrm{H}_{2} \mathrm{C}_{2} \mathrm{O}_{4}(40 \mathrm{mM}$, pH adjusted to 4.0$), \mathrm{K}_{2} \mathrm{C}_{2} \mathrm{O}_{4}(40 \mathrm{mM})$ and $\mathrm{KCl}(80 \mathrm{mM})$ treatment on $\mathrm{WK}(\mathbf{A})$ and $\mathrm{K}$ band (O-J normalized, $\mathbf{B}$ ) in tobacco leaves. Leaf discs (10 mm diameter) were infiltrated with $\mathrm{HCL}(\mathrm{pH} 4.0), \mathrm{H}_{3} \mathrm{PO}_{4}$ (pH 4.0), $\mathrm{H}_{2} \mathrm{C}_{2} \mathrm{O}_{4}(40 \mathrm{mM}$, pH adjusted to 4.0$), \mathrm{K}_{2} \mathrm{C}_{2} \mathrm{O}_{4}(40 \mathrm{mM})$ and $\mathrm{KCl}$ $(80 \mathrm{mM}$ ) under darkness for $3 \mathrm{~h}$, followed by exposure to intense light $\left(800 \mu \mathrm{mol} \mathrm{m}{ }^{-2} \mathrm{~s}^{-1}\right)$ for 2 hours. CK were leaves without any reagent treatment. Different letters indicate significant differences between leaves with different treatments $(P<0.05)$. Values were means $\pm S E(n=8)$.

Additional file 3: Figure S3. Effect of $\mathrm{HCl}(\mathrm{pH} 4.0), \mathrm{H}_{3} \mathrm{PO}_{4}(\mathrm{pH}$ 4.0), $\mathrm{H}_{2} \mathrm{C}_{2} \mathrm{O}_{4}(40 \mathrm{mM}, \mathrm{pH}$ adjusted to 4.0$), \mathrm{K}_{2} \mathrm{C}_{2} \mathrm{O}_{4}(40 \mathrm{mM})$ and $\mathrm{KCl}(80 \mathrm{mM})$ treatment on $\psi_{0}$ (A) and OJIP curves (O-P normalized, B) in tobacco leaves. Leaf discs (10 mm diameter) were infiltrated with $\mathrm{HCL}$ ( $\mathrm{pH}$ 4.0), $\mathrm{H}_{3} \mathrm{PO}_{4}$ (pH 4.0), $\mathrm{H}_{2} \mathrm{C}_{2} \mathrm{O}_{4}$ (40 mM, pH adjusted to 4.0), $\mathrm{K}_{2} \mathrm{C}_{2} \mathrm{O}_{4}(40 \mathrm{mM})$ and $\mathrm{KCl}(80 \mathrm{mM})$ under darkness for $3 \mathrm{~h}$, followed by exposure to intense light $\left(800 \mu \mathrm{mol} \mathrm{m}{ }^{-2} \mathrm{~s}^{-1}\right)$ for 2 hours. CK were leaves without any reagent treatment. Different letters indicate significant differences between leaves with different treatments $(P<0.05)$. Values were means \pm SE $(n=8)$.

Additional file 4: Figure S4. The $\mathrm{Pn}-\mathrm{CO}_{2}$ curves of tobacco leaves treated with different concentrations $(0,20,40,60 \mathrm{mM})$ of $\mathrm{K}_{2} \mathrm{C}_{2} \mathrm{O}_{4}$ and $120 \mathrm{mM} \mathrm{KCl}$. The petioles of detached leaves were dipped into treatment solutions before measurement in the dark for 3 hours. CK were leaves without $\mathrm{K}_{2} \mathrm{C}_{2} \mathrm{O}_{4}$ and $\mathrm{KCl}$ treatment.

Additional file 5: Figure S5. The effect of $40 \mathrm{mM} \mathrm{K}_{2} \mathrm{C}_{2} \mathrm{O}_{4}$ and $80 \mathrm{mM}$ $\mathrm{KCl}$ treatment on the $\mathrm{F}_{0}$ in tobacco leaves treated with high-light for 2 hours. $\mathrm{CK}$ were leaves without $\mathrm{K}_{2} \mathrm{C}_{2} \mathrm{O}_{4}$ and $\mathrm{KCl}$ treatment. Different letters indicate significant differences between leaves with different treatments $(P<0.05)$. Values were means \pm SE $(n=8)$.

\section{Abbreviations}

Am: Net photosynthesis rate in saturated $\mathrm{CO}_{2} ; \mathrm{CE}$ : Carboxylation efficiency; CM: Chloramphenicol; DAB: 3, 3-diaminobenzidine; $\mathrm{F}_{\mathrm{v}} / \mathrm{F}_{\mathrm{m}}$ : Maximal quantum yield of $\mathrm{PSIl} ; \mathrm{H}_{2} \mathrm{O}_{2}$ : Hydrogen peroxide; $\mathrm{Pn}$ : Net photosynthesis rate; PSI: Photosystem I; PSII: Photosystem II; RC/CSm: Density of $\mathrm{Q}_{A}$-reducing PSII reaction centres; ROS: Reactive oxygen species; RuBP: Ribulose-1,5bisphosphate; IAM: Iodoacetamide; S. sclerotiorum: Sclerotinia sclerotiorum (Lib.) de Bary; Wk: Normalized relative variable fluorescence at the K step; $\Pi_{0}$ : Exciton efficiency of electron transport beyond $\mathrm{Q}_{\mathrm{A}}$.

\section{Competing interests}

The authors declare that they have no competing interests.

\section{Authors' contributions}

$\mathrm{CY}$ performed most of the experiments and wrote the manuscript. $\mathrm{HG}$ and $\mathrm{CY}$ designed the study. HG directed the study and revised the manuscript. ZZ performed the measurement of cyclic electron transport, PSI activity, NPQ, QP and ETR, and helped to revised the manuscript. ML and XF helped in measuring OJPP transients. All authors read and approved the final manuscript.

\section{Acknowledgements}

This work was supported by the Specialized research fund for the doctoral program of higher education (20113702110008) and National natural science foundation of China (31370276).

\section{Author details}

'State Key Lab of Crop Biology, College of Life Sciences, Shandong Agricultural University, Tai'an, Shandong 271018, China. ${ }^{2}$ Wheat Research Center, Henan Academy of Agricultural Sciences, Zhengzhou, Henan 450002, China.

Received: 7 December 2013 Accepted: 4 September 2014

\section{2.}

\section{References}

1. Boland GJ, Hall R: Index of plant hosts of sclerotinia sclerotiorum. Can J Plant Pathol 1994, 16(2):93-108.

2. Bolton MD, Thomma BP, Nelson BD: Sclerotinia sclerotiorum (Lib.) de bary: biology and molecular traits of a cosmopolitan pathogen. Mol Plant Pathol 2006, 7(1):1-16.

3. Godoy G, Steadman JR, Dickman MB, Dam R: Use of mutants to demonstrate the role of oxalic acid in pathogenicity of sclerotinia sclerotiorum on phaseolus vulgaris. Physiol Mol Plant P 1990, 37(3):179-191.

4. Donaldson PA, Anderson T, Lane BG, Davidson AL, Simmonds DH: Soybean plants expressing an active oligomeric oxalate oxidase from the wheat gf-2.8 (germin) gene are resistant to the oxalate-secreting pathogen sclerotina sclerotiorum. Physiol Mol Plant P 2001, 59(6):297-307.

5. Burke JM, Rieseberg LH: Fitness effects of transgenic disease resistance in sunflowers. Science 2003, 300(5623):1250.

6. Bateman DF, Beer SV: Simultaneous production and synergistic action of oxalic acid and polygalacturonase during pathogenesis by sclerotium rolfsii. Phytopathology 1965, 55:204-211.

7. Kim H, Chen C, Kabbage M, Dickman MB: Identification and characterization of sclerotinia sclerotiorum NADPH oxidases. Appl Environ Microb 2011, 77(21):7721-7729.

8. Williams B, Kabbage M, Kim H, Britt R, Dickman MB: Tipping the balance: sclerotinia sclerotiorum secreted oxalic acid suppresses host defenses by manipulating the host redox environment. PLoS Pathog 2011, 7(6):e1002107.

9. Schulze Lefert P, Swarbrick PJ, Scholes JD: Metabolic consequences of susceptibility and resistance (race-specific and broad-spectrum) in barley leaves challenged with powdery mildew. Plant Cell Environ 2006, 29(6):1061-1076.

10. Bonfig KB, Schreiber U, Gabler A, Roitsch T, Berger S: Infection with virulent and avirulent $P$. syringae strains differentially affects photosynthesis and sink metabolism in Arabidopsis leaves. Planta 2006, 225(1):1-12.

11. Chou HM, Bundock N, Rolfe SA, Scholes JD: Infection of arabidopsis thaliana leaves with albugo candida (white blister rust) causes a reprogramming of host metabolism. Mol Plant Pathol 2000, 1(2):99-113.

12. Scholes JD, Rolfe SA: Photosynthesis in localised regions of oat leaves infected with crown rust (puccinia coronata): quantitative imaging of chlorophyll fluorescence. Planta 1996, 199(4):573-582.

13. Berger S, Papadopoulos M, Schreiber U, Kaiser W, Roitsch T: Complex regulation of gene expression, photosynthesis and sugar levels by pathogen infection in tomato. Physiol Plantarum 2004, 122(4):419-428.

14. Berger S, Sinha AK, Roitsch T: Plant physiology meets phytopathology: plant primary metabolism and plant-pathogen interactions. J Exp Bot 2007, 58(15-16):4019-4026.

15. Guimarães RL, Stotz HU: Oxalate production by sclerotinia sclerotiorum deregulates guard cells during infection. Plant Physiol 2004, 136(3):3703-3711.

16. Bu JW, Yao G, Gao HY, Jia YJ, Zhang LT, Cheng DD, Wang X: Inhibition mechanism of photosynthesis in cucumber leaves infected by sclerotinia sclerotiorum (Lib.) de bary. Acta Phytopathologica Sinica 2009, 39(6):613-621

17. Gao J, Li P, Ma F, Goltsev V: Photosynthetic performance during leaf expansion in malus micromalus probed by chlorophyll $a$ fluorescence and modulated $820 \mathrm{~nm}$ reflection. J Photochem Photobiol B 2014, 137(8):144-150.

18. Oukarroum A, Goltsev V, Strasser RJ: Temperature effects on pea plants probed by simultaneous measurements of the kinetics of prompt fluorescence, delayed fluorescence and modulated $820 \mathrm{~nm}$ reflection. PLoS One 2013, 8(3):e59433.

19. Zhang Z, Jia Y, Gao H, Zhang L, Li H, Meng Q: Characterization of PSI recovery after chilling-induced photoinhibition in cucumber (cucumis sativus L.) leaves. Planta 2011, 234(5):883-889. 
20. Björkman $\mathrm{O}$, Demmig B: Photon yield of $\mathrm{O}_{2}$ evolution and chlorophyll fluorescence characteristics at $77 \mathrm{~K}$ among vascular plants of diverse origins. Planta 1987, 170(4):489-504.

21. Vonshak A, Torzillo G, Tomaseli L: Use of chlorophyll fluorescence to estimate the effect of photoinhibition in outdoor cultures of spirulina platensis. J Appl Phycol 1994, 6(1):31-34.

22. Maxwell DP, Lumsden RD: Oxalic acid production by sclerotinia sclerotiorum in infected bean and in culture. Phytopathology 1970, 60(9):1395-1398.

23. Zhou T, Boland GJ: Mycelial growth and production of oxalic acid by virulent and hypovirulent isolates of sclerotinia sclerotiorum. Can J Plant Pathol 1999, 21(1):93-99.

24. Cessna SG, Sears VE, Dickman MB, Low PS: Oxalic acid, a pathogenicity factor for sclerotinia sclerotiorum, suppresses the oxidative burst of the host plant. Sci Signal 2000, 12(11):2191.

25. Noyes RD, Hancock JG: Role of oxalic acid in the sclerotinia wilt of sunflower. Physiol Plant Pathol 1981, 18(2):123-132

26. Nishiyama Y, Allakhverdiev SI, Murata N: Protein synthesis is the primary target of reactive oxygen species in the photoinhibition of photosystem II. Physiol Plant 2011, 142(1):35-46.

27. Zhang LT, Zhang ZS, Gao HY, Xue ZC, Yang C, Meng XL, Meng QW: Mitochondrial alternative oxidase pathway protects plants against photoinhibition by alleviating inhibition of the repair of photodamaged PSIl through preventing formation of reactive oxygen species in rumex K-1 leaves. Physiol Plant 2011, 143(4):396-407.

28. Farquhar GD, von von Caemmerer S, Berry JA: A biochemical model of photosynthetic $\mathrm{CO}_{2}$ assimilation in leaves of C3 species. Planta 1980, 149(1):78-90.

29. Yamanaka R, Nakamura K, Murakami A: Reduction of exogenous ketones depends upon NADPH generated photosynthetically in cells of the cyanobacterium synechococcus PCC 7942. AMB Express 2011, 1(1):1-8.

30. Xu Z, Luo G, Ke D, Chen J, Chen Y, Wang A: Chlorophyll fluorescence quenching induced by superoxide anion. Prog Biochem Biophys 2002, 29(1):139-143.

31. Pedras MSC, Ahiahonu PW: Phytotoxin production and phytoalexin elicitation by the phytopathogenic fungus sclerotinia sclerotiorum. J Chem Ecol 2004, 30(11):2163-2179.

32. Hollowell JE, Shew BB: Yellow nutsedge (cyperus esculentus L.) as a host of sclerotinia minor. Plant Dis 2001, 85(5):562.

33. Strasser BJ: Donor side capacity of photosystem II probed by chlorophyll a fluorescence transients. Photosynth Res 1997, 52(2):147-155.

34. Zhang Z, Li G, Gao H, Zhang L, Yang C, Liu P, Meng Q: Characterization of photosynthetic performance during senescence in stay-green and quick-leaf-senescence Zea Mays L. Inbred lines. Plos One 2012, 7(8):e42936

35. Strasser RJ, Tsimilli-Michael M, Srivastava A: Analysis of the chlorophyll a fluorescence transient. In Chlorophyll a Fluorescence: A Signature of Photosynthesis, Volume Volume 19. Edited by Papageogiou GC, Govindjee. Dordrecht: Springer; 2004:321-362.

36. Anderson JM, Chow WS: Structural and functional dynamics of plant photosystem II. Philos Trans R Soc Lond B Bio/ Sci 2002, 357(1426):1421-1430.

37. Tyystjärvi $E$, Aro $E$ : The rate constant of photoinhibition, measured in lincomycin-treated leaves, is directly proportional to light intensity. Proc Natl Acad Sci U S A 1996, 93(5):2213-2218.

38. Aro E, Virgin I, Andersson B: Photoinhibition of photosystem II. Inactivation, protein damage and turnover. Biochim Biophys Acta 1993, 1143(2):113-134.

39. Nishiyama Y, Allakhverdiev SI, Murata N: A new paradigm for the action of reactive oxygen species in the photoinhibition of photosystem II. Biochim Biophys Acta 2006, 1757(7):742-749.

40. Takahashi S, Murata N: How do environmental stresses accelerate photoinhibition? Trends Plant Sci 2008, 13(4):178-182.

41. Murata N, Takahashi S, Nishiyama Y, Allakhverdiev SI: Photoinhibition of photosystem II under environmental stress. Biochim Biophys Acta 2007 1767(6):414-421

42. Apel K, Hirt H: Reactive oxygen species: metabolism, oxidative stress, and signal transduction. Annu Rev Plant Biol 2004, 55:373-399.

43. Shen $\mathrm{BO}$, Jensen $\mathrm{RG}$, Bohnert $\mathrm{HJ}$ : Increased resistance to oxidative stress in transgenic plants by targeting mannitol biosynthesis to chloroplasts. Plant Physiol 1997, 113(4):1177-1183.

44. Edreva A: Generation and scavenging of reactive oxygen species in chloroplasts: a submolecular approach. Agr Ecosyst Environ 2005, 106(2):119-133.
45. Rosa L, Whatley FR: Conditions required for the rapid activation in vitro of the chloroplast fructose-1, 6-bisphosphatase. Plant Physiol 1984, 75(1):131-137

46. Hertig C, Ricardo A, Wolosiuk RA: A dual effect of $\mathrm{Ca}^{2+}$ on chloroplast fructose-1, 6-bisphosphatase. Biochem Biophys Res Commun 1980, 97(1):325-333.

47. Liang C, Xiao W, Hao H, Xiaoqing L, Chao L, Lei Z, Fashui H: Effect of Mg $^{2+}$ on the structure and function of ribulose-1, 5-bisphosphate carboxylase/ oxygenase. Biol Trace Elem Res 2008, 121(3):249-257.

48. Kim KS, Min J, Dickman MB: Oxalic acid is an elicitor of plant programmed cell death during sclerotinia sclerotiorum disease development. Mol Plant Microbe In 2008, 21(5):605-612.

49. Scandalios JG: Oxygen stress and superoxide dismutases. Plant Physiol 1993, 101(1):7

50. Macpherson AN, Telfer A, Barber J, Truscott TG: Direct detection of singlet oxygen from isolated photosystem II reaction centres. Biochim Biophys Acta 1993, 1143(3):301-309.

51. Hideg É, Spetea C, Vass I: Singlet oxygen production in thylakoid membranes during photoinhibition as detected by EPR spectroscopy Photosynth Res 1994, 39(2):191-199.

52. Walz A, Zingen-Sell I, Theisen S, Kortekamp A: Reactive oxygen intermediates and oxalic acid in the pathogenesis of the necrotrophic fungus sclerotinia sclerotiorum. J Plant Pathol 2008, 120(4):317-330.

53. Haldimann P, Strasser RJ: Effects of anaerobiosis as probed by the polyphasic chlorophyll $a$ fluorescence rise kinetic in pea (pisum sativum L.). Photosynth Res 1999, 62(1):67-83.

54. Srivastava A, Jüttner $F$, Strasser RJ: Action of the allelochemical, fischerellin A, on photosystem II. Biochim Biophys Acta 1998, 1364(3):326-336.

55. Maxwell K, Johnson GN: Chlorophyll fluorescence-a practical guide. J Exp Bot 2000, 51:659-668.

56. Thordal Christensen $\mathrm{H}$, Zhang Z, Wei Y, Collinge DB: Subcellular localization of $\mathrm{H}_{2} \mathrm{O}_{2}$ in plants. $\mathrm{H}_{2} \mathrm{O}_{2}$ accumulation in papillae and hypersensitive response during the barley-powdery mildew interaction. Plant J 1997, 11(6):1187-1194.

57. Dubois M, Gilles KA, Hamilton JK, Rebers PT, Smith F: Colorimetric method for determination of sugars and related substances. Anal Chem 1956, 28(3):350-356

58. Strasser RJ, Tsimilli-Michael M, Qiang S, Goltsev V: Simultaneous in vivo recording of prompt and delayed fluorescence and $820-\mathrm{nm}$ reflection changes during drying and after rehydration of the resurrection plant haberlea rhodopensis. Biochim Biophys Acta 2010, 1797(6):1313-1326.

\section{doi:10.1186/s12870-014-0240-4}

Cite this article as: Yang et al:: Mechanisms by which the infection of Sclerotinia sclerotiorum (Lib.) de Bary affects the photosynthetic performance in tobacco leaves. BMC Plant Biology 2014 14:240.

\section{Submit your next manuscript to BioMed Central and take full advantage of:}

- Convenient online submission

- Thorough peer review

- No space constraints or color figure charges

- Immediate publication on acceptance

- Inclusion in PubMed, CAS, Scopus and Google Scholar

- Research which is freely available for redistribution 